\title{
The Second Anglo-Boer War: An Overview
}

\section{Fransjohan Pretorius}

Two definite phases can be discerned in the Second Anglo-Boer War of 1899 to 1902: the conventional (setpiece-battle) phase from the outbreak of the war on 11 October 1899 to the Battle of Dalmanutha (Bergendal) between 21 and 27 August 1900; and the guerrilla phase from September 1900 to the end of the war on 31 May 1902. However, it makes more sense to add a transitional phase, stretching from March to August 1900, which contains characteristics of both major phases. With the conventional phase we specifically mean that period when the two opposing forces were mustered against each other on the battleground and both attempted to defeat or push back the other in a direct confrontation. That is, when the opposing armies both pursued a combat strategy. The nature of the guerrilla phase - marked by a change in the Boer strategy - will be discussed below.

\section{The conventional phase, 11 October 1899 to 28 February 1900}

By September 1899 it was apparent that there was little chance of the diplomatic struggle between the Zuid-Afrikaansche Republiek (ZAR or Transvaal) and Great Britain being resolved without a military confrontation. On 27 September in order to counter the massing of British troops on the Republican borders, CommandantGeneral Piet Joubert called up about $60 \%$ of the white male population of the Transvaal between 16 and 60 years of age - about 32000 men - for military service. Five days later President M.T. Steyn mobilised the Orange Free State burghers, honouring the offensive and defensive alliance it had concluded in March 1897 with the Transvaal.

On 9 October the government of the Transvaal sent Britain an ultimatum demanding that the differences between the two states be settled by means of arbitration, that the British troops on the borders should be withdrawn immediately, and that the troops embarked for South Africa not land there. The British government rejected the ultimatum, and consequently Britain and the Transvaal were at war with effect from 11 October 1899. Honouring its alliance the Free State joined the Transvaal in their war effort.

The Boer high command sent forces to four fronts in order to halt the expected British invasions - the Natal front in the wedge where the Natal, Free State and Transvaal borders met and where the bulk of the two hostile armies were positioned opposite one another; the extensive southern front where the Free State adjoined the Cape Colony and which extended from Barkly East in the east, through Aliwal North, Bethulie and Norvalspont along the Orange River to a point past Philippolis and 
Colesberg in the west; the western front (equally difficult to defend) where the Free State and the Transvaal adjoined the Cape Colony and the Bechuanaland Protectorate, from Hopetown in the south, past Magersfontein, Kimberley and Vryburg to the north of Mafeking; and the northern front in the northwestern and Northern Transvaal where British attacks from Rhodesia across the Limpopo had to be countered.

With the outbreak of hostilities the bulk of the British troops had not yet arrived in South Africa, giving the Boer forces the opportunity to take the initiative in the offensive. The objective of the Boer command was to isolate or wipe out the British forces threatening the republics on their borders, and to occupy suitable positions in enemy territory where the Boer forces could halt the advance of British reinforcements moving up from the coast.

The first military encounter of the war took place on 12 October at Kraaipan on the western front where General Koos de la Rey captured a British armoured train. This was followed by two British victories at Talana (Dundee) and Elandslaagte on the Natal front (on 20 and 21 October respectively). The Boers won important victories at Modderspruit and Nicholsonsnek on 30 October, forcing General Sir George White to take refuge in Ladysmith. A consequence of the Boer offensive was their siege of Mafeking (13 October), Kimberley (14 October) and Ladysmith (2 November), all in British territory.

Boer siege mentality had come a long way. In the second half of the nineteenth century the Boers developed a peculiar method of warfare in their conflict with the African societies within their republics. Since attacks on fortified strongholds of the Africans entailed risking heavy casualties among the assailants, the Boers came to rely very heavily on protracted sieges. In military terms the Boers strategically took the offensive by going out to meet the enemy but then tactically went on the defensive by laying siege to their strongholds. Attack would invariably lead to loss of life and their small numbers were too valuable for the Boers to risk lives. With their experience of siege tactics against the African communities Boer sieges were again to become a major feature of the First Anglo-Boer War of 1880-1881. The idea of saving lives to fight another day had become doctrine long before the Second Anglo-Boer War of 18991902.

While the Boer forces advanced sluggishly at the outbreak of the war, British reinforcements continued to arrive in South Africa. British campaign strategy had originally intended General Sir Redvers Buller, as Commander-in-Chief of the British forces in South Africa, to march via the Cape Colony along the railway line (which would provide him with vital provisions) and conquer the Boer republics from the south. However, White's setback in Natal drastically altered the situation. On his arrival in Cape Town on 31 October, Buller therefore decided rather to relieve Kimberley and Ladysmith as soon as possible and halt the Boer offensive in Natal and the northern Cape. With this in mind, Lord Methuen was to march along the western railway line to relieve Kimberley. Major-General Sir John French at Colesberg and Lieutenant-General Sir William Gatacre near Stormberg were to repulse the Boer invasion of the Cape Colony. Buller would himself undertake the more difficult task of recapturing northern Natal and relieving Ladysmith. The first British offensive swung into motion. 
On the western front Methuen was successful at Belmont, Graspan and Modder River (Tweeriviere), respectively on 23, 25 and 28 November. However, with their frontal attacks and inadequate reconnaissance work the British generals (Buller in Natal and Methuen on the western front) made the task of the well-camouflaged, entrenched Boers an easy one. The British defeats at Stormberg on the southern front on 10 December at the hands of General J.H. Olivier, Magersfontein the next day on the western front against Generals Piet Cronjé and Koos de la Rey, and Colenso on 15 December on the Natal front against General Louis Botha were known among the British as 'Black Week'.

The victory at Magersfontein can be attributed to De la Rey, Cronjé's junior officer. His experience at Graspan had convinced him that the hills were not the best line of defence, but rather the plain at the foot of the hills. Anticipating that Methuen would direct his attack at the hills, De la Rey, with the assistance of President Steyn, persuaded Cronjé that the burghers dig themselves into a concealed line of trenches about a metre deep and a metre wide - in front of and parallel to the hills. The burghers could stand upright and shoot over breastworks of soil camouflaged by branches and grass.

De la Rey's trenches at Magersfontein were not the first in modern warfare: trenches had been used in the Crimean War of 1854-1856. Nevertheless De la Rey's unusual decision to position his trenches on the plains in front of the hills marked him as a superior tactician.

In Natal Buller had amassed more than 21000 troops with 46 guns south of the Tugela River by mid-December. In the hills along the northern bank General Louis Botha and his 4500 Transvalers and five guns blocked his way to Ladysmith. Along the Upper Tugela 2000 Free Staters were in support. Botha had his burghers dig trenches and build outworks of rocks and sandbags in front of the hills near the river. Eventually some 3000 burghers were to take part in the Battle of Colenso on 15 December 1899.

Unimaginatively, Buller decided on a frontal attack. Hopelessly inadequate reconnaissance had failed to determine the positions of the Boer entrenchments in front of the hills. Fatally, he also failed to correct the mistakes on his maps. On the morning of 15 December, warned by two days' continuous bombardment of the hills behind them, the Boers in their concealed positions unleashed a hail of rifle and gun fire on the advancing enemy across the Tugela. Buller suffered a disastrous defeat. Boer losses totalled 38, but Buller lost at least 1139 men.

When his first attempt to relieve Ladysmith ended in dismal failure, Buller heliographed a message to General White in Ladysmith advising that if he could not last out another month, he was to expend as much ammunition as possible and accept the most favourable terms. This message has contributed much to the criticism levelled at Buller over the years.

Botha followed his success at Colenso against Buller with an important victory at Spioenkop on 24 January. The Battle of Spioenkop had in fact begun on 16 January with British troops crossing the Tugela under Lieutenant-General Sir Charles Warren. His mission was to take Spioenkop in order to threaten the Boers on Tabayama 
Hill. There, on Spioenkop, the British column of 2000 men under Major-General E.R.P. Woodgate was pinned down by the Boers on the morning of 24 January. Some 400 burghers under Commandant Hendrik Prinsloo of Carolina and Commandant 'Rooi' Daniël Opperman of Pretoria district stormed up Spioenkop and opened fire on the British with deadly accuracy. From the hills rising in a crescent around Spioenkop, rifles and guns spewed destruction. In the biggest battle of the war the British suffered their most serious reverse. In the nine days the toll on the British side was between 2500 and 2700 casualties, of which between 1800 and 2000 occurred on 24 January alone. Boer losses totalled less than 200 .

Botha repulsed a third attempt by Buller to relieve Ladysmith at Vaalkrans (5-7 February). Buller's defeat here must be attributed again to his poor intelligence regarding the Boer positions across the Tugela, as well as the courage of the Johannesburg Commando and the Boer artillery.

By the beginning of February 1900 the first British offensive was a failure, not only on the Natal front, but also on the southern and the western fronts. The Boer leaders did not exploit this. Their victories had placed the Boers in a position to resume the initiative, to encircle the enemy, particularly in the Cape Colony, and to destroy the railway lines behind Methuen and Gatacre. Presidents Kruger and Steyn had urged these moves upon Cronjé; and Generals De la Rey and De Wet were prepared to take on the campaign with 1500 burghers. But Cronjé refused to weaken his force to this extent, failing to realise that the Boers could have taken the important railway junctions at De Aar and even Naauwpoort - a manoeuvre that would have seriously hampered Roberts' advance to the Free State.

On the northern front the small number of British troops in Rhodesia (now Zimbabwe) were kept in check by a Boer force of some 2000 under General F.A. Grobler. When a month passed without Grobler taking the offensive, the campaign was abandoned.

On 10 January 1900 Lord Roberts arrived in South Africa to replace Buller as the commander-in-chief of the British forces. Buller and Methuen's tactics of frontal attacks were replaced by outflanking manoeuvres. In this way General Sir John French relieved Kimberley on 15 February. The British were now between Cronjé at Magersfontein and the Free State. To avoid being cut off, Cronjé was forced to retreat eastwards. On 18 February Lord Kitchener attacked him at Paardeberg on the north bank of the Modder River. Boer losses were minimal, but Kitchener lost 1270 men in what was to be one of the largest casualty totals for a single day during the war. Cronjé, however, had suffered a serious setback: so many of his horses and draught animals had been killed in the battle that the wagon laager could not be moved to safer terrain. $\mathrm{He}$ was encircled by Roberts and was eventually forced to surrender with 4000 men to the British commander-in-chief at Paardeberg on 27 February. The western front collapsed and the burghers fled in confusion. Two weeks later, on 13 March, Roberts occupied Bloemfontein.

With the threat of being cut off in the north, the burghers on the southern front retreated as well, and the southern front collapsed too. Between February and 
April they were obliged to retreat in scattered commandos through the Eastern Free State.

On the Natal front Buller eventually organized a flank attack and broke through the Boer lines on 27 February. The Boers around Ladysmith fell back to the Biggarsberg and Drakensberg mountains and Ladysmith was relieved on 28 February. The second British offensive had succeeded on all three fronts.

\section{The transitional phase, March to August 1900}

The disaster that had befallen Cronjé and his immobile wagon laager held a lesson for the Boer military command. At a council of war held at Kroonstad on 17 March it was decided to continue the struggle with mounted commandos and without large wagon laagers. This was an important step in the direction of guerrilla warfare.

Dynamic leaders had emerged in the persons of Christiaan de Wet in the Free State and Louis Botha and Koos de la Rey in the Transvaal. After the death of Piet Joubert on 27 March 1900, Botha succeeded him as head of the Transvaal forces.

De Wet, now Chief Commandant in the Free State, became the most important exponent of the new style of mobile warfare. His favourite targets were the isolated British columns Roberts had spread along the Bloemfontein-Pretoria railway line and later throughout the Southern and southeastern Free State. With his attack on the Bloemfontein waterworks at Sannaspost, $28 \mathrm{~km}$ east of the Free State capital, De Wet achieved one of his most brilliant victories. On the morning of 31 March his brother, General Piet de Wet, opened fire from the east on Brigadier-General R.G. Broadwood's camp at Sannaspost. The British, hastily fleeing in the direction of Bloemfontein, ran into the ambush prepared for them by Christiaan de Wet, lying in wait with 350 men in the Koornspruit. Broadwood suffered heavily in the ensuing battle.

On 4 April Christiaan de Wet followed up his success at Mostersthoek near Reddersburg, attacking an isolated British column, but at the Sand River on 10 May he and Louis Botha were unable to prevent Roberts from advancing along the railway line towards the Vaal River. The Transvaal commandos retreated into their heartland, and on 28 May Roberts annexed the Free State as the Orange River Colony. Meanwhile Mafeking which had held out bravely under Colonel R.S.S. Baden-Powell had been relieved on 17 May.

Although Lieutenant-General Ian Hamilton suffered heavy losses in a battle against De la Rey at Doornkop, near Roodepoort, on 29 May, Johannesburg and the mines of the Witwatersrand fell into Roberts's hands two days later. On 5 June 1900 Roberts occupied Pretoria. President Paul Kruger and the Transvaal government had fled eastwards to Machadodorp along the Delagoa Bay railway line a week before.

Roberts decided to drive off the Transvaal commandos under Botha lurking to the east of Pretoria. On 11 and 12 June, a week after the fall of the Boer capital, the Battle of Diamond Hill (Donkerhoek) raged about $30 \mathrm{~km}$ east of the town. On the afternoon of 12 June Ian Hamilton broke through the Boer lines on the southern flank at 
Diamond Hill. The Transvalers under Botha were forced to retreat in an easterly direction along the Delagoa Bay railway line to protect their rear against Buller's advance from Natal, thus enabling French to occupy Middelburg on 27 July.

Following Diamond Hill De la Rey was sent to the Western Transvaal in early July to recapture the area and effect a Boer revival there. He immediately began with a victory at Silkaat's Nek on 11 July - about $30 \mathrm{~km}$ west of Roberts's headquarters in Pretoria. This success attracted large numbers of burghers who had laid down arms back to the commandos. De la Rey's half-hearted siege between 4 and 16 August of the British camp on the Elands River (where Zwartruggens is today) was a failure. Accompanied by the ZAR State Atorney, J.C. Smuts, De la Rey left the siege and proceeded to Zeerust and Lichtenburg. Here he made important civil arrangements, including appointing magistrates for the area. The guerrilla phase was about to begin in the Western Transvaal.

In the meantime events in the Free State had not gone Roberts's way. The British commander-in-chief, who had thought the war was over with the occupation of Pretoria, soon realised that the Boers - particularly the Free Staters - intended to continue the resistance, as the success of Generals A.J. de Villiers at Biddulphsberg on 29 May and Piet De Wet two days later against the Imperial Yeomanry at Lindley proved.

The vulnerability of Roberts's line of communication was best illustrated by Christiaan de Wet's attack on Roodewal station to the north of Kroonstad on 7 June. Besides losing large stocks of clothing and ammunition worth $£ 100$ 000, Roberts found himself in telegraphic isolation two days after his occupation of Pretoria.

It was clear to Roberts that he had to counter De Wet's operations. His proclamations of 31 May and 1 June 1900 which had been issued to discourage the burghers were followed up by another 'paper bomb' on 16 June: if the Boers destroyed rail and telegraph connections, the houses in the vicinity of such strikes would be burnt. That very morning De Wet's homestead near Roodewal was razed by fire. Roberts was in fact legalising by proclamation a punitive measure that had been applied sporadically since January 1900. Thus the 'scorched earth' policy was not, as is often thought, launched by Kitchener in 1901 .

With the burning of the farmhouses a major problem was what to do with the growing number of homeless Boer women and children. In this way the concentration camp system was introduced by about July 1900 . Housed in the camps from the start were also Boers who had laid down their arms and their families, to prevent the men from being re-commandeered by the Boers.

Driving the Free State forces eastwards Major-General Sir A.H. Paget and Major-General R.A.P. Clements captured Bethlehem on 7 July. The Free State government and the commandos retired behind the Wittebergen into the Brandwater Basin. Before Lieutenant-General Sir Archibald Hunter could close off the cordon, De Wet and President Steyn slipped past him and escaped from the Brandwater Basin on 15 July 1900, taking with them the Free State government and 2000 men. 
The rest of the Free State commandos were to leave the mountains in three groups, but while dissension over the leadership was paralysing them, Hunter occupied the exit passes. General Piet Fourie with some 1500 men escaped, but on 30 July Marthinus Prinsloo surrendered with twice as many men, the number swelling to 4400 within a week. In this way half of the Free Staters still in the field were eliminated from the war effort.

With De Wet still at large, Roberts believed that the war would be ended if he succeeded in capturing the Boer Pimpernel, and initiated a large-scale chase since known as the 'first De Wet hunt'. British columns from all quarters joined in the hunt until there were more than 50000 men mustered against the elusive Boer general in a chase across the Eastern and Northern Free State and the Western Transvaal. De Wet succeeded in escaping the British net on 14 August by crossing the Magaliesberg at Olifant's Nek near Rustenburg.

Excellent tactics, combined with mobility, strict discipline and the efficiency of the scouts led by Commandant Danie Theron and Captain Gideon Scheepers, were largely responsible for De Wet's success. The weakness of the British communications and intelligence systems, as well as their disrupted supplies, were also to De Wet's advantage.

On 28 August the executive councils of the two republics decided in a joint session at Waterval Onder to send the ageing President Kruger via Delagoa Bay to Europe, where he was to seek the intervention of European governments to secure peace with the preservation of independence for the republics. Schalk Burger was appointed Acting President of the ZAR. Kruger's mission failed since no European government was prepared to act against Britain's interests, and he remained an exile until his death in 1904.

Only when the first De Wet hunt had ended in failure was Roberts able to return his attention to his advance along the Delagoa Bay railway line. On 15 August the forces under Roberts from Pretoria and Buller from Natal were united. Roberts's force in the Eastern Transvaal now consisted of more than 20000 men. With only 5000 Transvalers to defend his line, Botha offered fierce resistance in the last setpiece battle of the war at Dalmanutha (Bergendal) between 21 and 27 August 1900, the handful of ZARPS - policemen of the ZAR - bearing the brunt of the heavy British bombardment. Roberts's superiority in artillery proved decisive, however, and the Transvalers were forced to retreat further eastwards.

\section{The Guerrilla Phase, September 1900 to May 1902}

Convinced that he had crushed the Boers, Roberts annexed the Transvaal to Her Majesty's dominions on 1 September 1900. Three week later his columns reached Komatipoort, on the border of Portuguese East Africa. The entire Transvaal south of the Delagoa Bay railway line was now in British hands - or so it appeared. In reality, his authority reached no farther than the range of his artillery, or the spot where his columns stood at any given moment. As soon as a British column moved off, a commando would return and reinstate Boer authority. The war was far from over. 
The guerrilla war entered a new phase when De Wet and Botha began sending the commandos back to their respective districts, with orders to engage the British whenever the opportunity arose. Commandos were split into small groups that were easier to conceal; when an isolated British column was sighted, the commando could be re-assembled at lightning speeds to mount a surprise attack. Mobility was the key to Boer strategy, with the mounted commandos in a position to be active, while the burghers who had no horses could hide in laagers in remote areas.

A thorough reorganisation of the Boer forces took place. Capable officers were appointed in place of those who had proved inefficient. Under the new arrangements, burghers who had taken the oath of neutrality and returned to their farms were called up again. The most active organisers were De la Rey in the Western Transvaal and De Wet in the Free State. Their efforts and encouragement caused many burghers to rejoin the commandos, to a certain extent compensating for the surrender of Prinsloo in the Free State and the reverses the Transvalers had suffered since the surrender of Cronjé. By September 1900 the war had taken on a character entirely different from that of the preceding year.

Meanwhile the adoption of guerrilla tactics heralded a period of reverses for De Wet. Between 20 and 25 October he and Liebenberg besieged Major-General G. Barton at Frederikstad Station in the Western Transvaal, but co-operation among the Boer officers was poor and when Barton's reinforcements arrived, the Boers were obliged to withdraw, leaving at least 26 of their number dead.

Early on 6 November De Wet and President Steyn were surprised near Bothaville by Lieutenant-Colonel P. le Gallais, who found the Boer sentries fast asleep. Le Gallais died of his wounds that evening, but 114 Boers were taken prisoner, including members of the Free State Executive. De Wet and Steyn escaped with the rest of the burghers to continue Boer resistance. Steyn's leadership was a true inspiration to the burghers: he firmyl believed that the republican ideal would triumph. He was indeed the soul of the Boers' struggle for freedom.

Attention could at last be given to De Wet's long-cherished ideal of invading the Cape Colony. When the republican forces had been withdrawn from the southern and western fronts in March 1900, the Cape rebels had been left in the lurch. Hope now rose that a new invasion would once more encourage Cape Afrikaners to join the Boer forces. Moreover, the extension of the theatre of war to the Cape Colony would considerably complicate the task of the British, who would have to withdraw troops from the Free State and the Transvaal to ward off this new threat.

On their way south De Wet and his 1500 mounted burghers forced the British garrison at Dewetsdorp to surrender on 23 November, and 408 British were taken prisoner. However, the delay enabled three flying British columns under General C.E. Knox to pursue the Boer Pimpernel in the second De Wet hunt, while thousands of troops were despatched by rail from the Transvaal.

A section of De Wet's men under General J.B.M. Hertzog succeeded in shaking off his pursuers and penetrated to Lamberts Bay on the Atlantic coast. By the end of February 1901 he was back in the Free State. Meanwhile heavy rains impeded 
De Wet and contributed to the failure of his campaign. The Orange River was in flood and across the river British columns waited, while Knox was threatening him from the rear. Privation took a heavy toll of De Wet's men and animals. But his mobility enabled him to escape from the triangle formed by the Basutoland border and the confluence of the Orange and Caledon Rivers. On 14 December 1900 he made a spectacular breakthrough at Sprinkaansnek near Thaba Nchu, when his burghers dashed through a rain of bullets between two British forts. Commandant (later General) P.H. Kritzinger and Gideon Scheepers held back at the Orange River and later operated in the Cape Colony.

At the end of January 1901 De Wet made a second attempt to invade the Cape Colony. From all over Kitchener rushed in troops by rail and launched the third De Wet hunt: some 14,000 British troops in 17 flying columns descended upon the Boer force of 3000 men. De Wet's well-tried ruse of constant feints kept his pursuers confused about his direction of travel, and he crossed the Orange to the west of Philippolis on 10 February. However, lack of grazing for the horses hampered his mobility. Many burghers had to walk 18 hours a day, carrying their rifles, saddles and blankets. Once again the rain frustrated their plans: De Wet was held back by the flooded Brak River, until on 28 February he was finally able to find a way back into the Free State through the Orange River.

De Wet's second invasion attempt of the Cape Colony was a complete failure. He had failed to rally large numbers of Cape Afrikaners to his cause in an operation that had proved his most difficult to date, involving exceptional demands and privations. $\mathrm{He}$ had finally lost the strategic intiaitive, and from this point on would be largely committed to defensive guerrilla warfare.

In the Eastern Transvaal a period of comparative calm followed the Battle of Dalmanutha, since the Boer commandos in general avoided engagement with the numerically superior British forces. However, in a nocturnal attack on 28-29 December 1900, General Ben Viljoen overwhelmed an isolated British garrison at Helvetia, near Machadodorp.

In the final months of 1900 De la Rey and the combat-generals under his command in the Western Transvaal constantly harassed the British. On 3 December he captured a convoy of 126 wagons bound for Rustenburg with Christmas supplies for the British troops. Ten days later he, General C.F. Beyers and General J.C. Smuts, with 2 500 burghers in all, followed this up with a victory over General R.A.P. Clements at Nooitgedacht.

Clements' camp, comprising 1500 men, lay in a kloof at Nooitgedacht, at the foot of the southern slopes of the Magaliesberg. On the peak above, some 300 British troops manned a heliographic station. Early on the morning of 13 December the Boers attacked from the west - Beyers along the crest of the mountain, and De la Rey and Smuts along the southern slopes of the mountain. Beyers' occupation of the peak, which enabled his burghers to fire on the camp in the kloof below, decided the battle. But because Smuts failed to block Clements' line of retreat and De la Rey's men began plundering the British camp, Clements succeeded in escaping with nearly two-thirds of 
his force. Boer casualties numbered 78, while the British had lost 332 men through casualties and 306 taken prisoner. The Boers had acquired as booty a large quantity of provisions, draught animals, rifles and ammunition, in a victory that raised the morale of the Western Transvalers.

There were some flaws in De la Rey's victory at Nooitgedacht. His attack had not been efficiently co-ordinated with Beyers' attack, and his men were still to learn the discipline he was to force upon them in the later stages. Still, his planning had been outstanding, his information had been acurate and he knew the terrain. He had also employed two vital principles of warfare: speed and surprise.

Everywhere the guerrilla war was taking root. Boer optimism was mounting, and when Kitchener assumed command from Roberts on 29 November 1900, the war was still far from over.

With 210000 troops at his disposal, Kitchener made every effort to alter an unfavourably military situation. But close on 100000 of these men were spread out with passive duties along the railway lines or as isolated garrisons. For guerrilla warfare the mounted infantry and cavalry were undoubtedly his most important troops. He therefore immediately called for mounted reinforcements.

Kitchener employed a threefold strategy to end the war. Firstly, he continued Roberts' scorched earth policy. The republics were subjected to a systematic devastation. Whole towns, as well as thousands of farmhouses, were destroyed or extensively damaged by fire. This onslaught on the Boers' means of survival was intensified by the destruction of all food supplies: livestock was killed in enormous numbers, and fields of grain and maize were burnt and destroyed.

As a second strategy, the concentration camp system was extended as more civilians, chiefly women and children, were interned. Kitchener was hoping that the men would surrender to join up with their families.

Thirdly, he began his 'drives' - a method to drive the commandos out in front of his troops and trap them against lines of blockhouses and barbed wire erected for this purpose in a network spanning the entire theatre of the war.

On 28 January 1901 Kitchener launched his first great drive with seven columns of 14,000 troops and 58 guns. His target was the Transvaal Highveld, between the Delagoa Bay and Natal railway lines. Most of the commandos offered no resistance, since they knew that they were hopelessly outnumbered, but they did succeed in breaking through the British lines in smaller numbers. Behind the lines they were safe for the time being, though the destruction sown by the advancing British brought great shortages of food.

Among those who broke through the lines was Louis Botha, who attacked Major-General H.L. Smith-Dorrien at Chrissiesmeer on 6 February. Eventually the British columns had advanced through the districts of Ermelo, Piet Retief, Vryheid and Utrecht, until they had reached the Natal border in mid April 1901. 
With winter at hand, a part of the Transvaal that had been prosperous before the war lay devastated. Homesteads had been burnt down, farm stock slaughtered or carried off, and most of the civilians sent to concentration camps. Yet the number of burghers eliminated from the battle area by Kitchener's drives, chiefly through their own voluntary surrender, was insignificant. Out of a total of 132, most were either old or very young - or they were the feint-hearted, who were of little use to the Boer cause.

Meanwhile Kitchener and Botha had met at Middelburg on 28 February 1901 for peace talks, at Kitchener's suggestion. He was fairly lenient in his peace proposals, but his most important demand - that the republics should surrender their independence and become British colonies - was unacceptable to Botha. This ensured the continuation of the war.

Kitchener began extending systematically the application of his scorched earth policy. The Free State and Transvaal were ravaged, so that the winter of 1901 brought the utmost privation to the burghers and their families. The commandos grew less active and avoided any encounter with the British. Boer women fled into the veld in small groups to avoid being sent to the concentration camps. The commandos, cut off from their sources, supplemented their supplies of food, clothing, rifles and ammunition by attacks on isolated British detachments. The Boers were no longer able to keep prisoners of war, and released them immediately after capture.

In these circumstances, despair overtook some Boer leaders, including Acting President Burger. The Free State leaders and others were aggrieved at this loss of courage and on 20 June 1901 President Steyn and Generals De Wet and De la Rey were among those who tried to rally the feint-hearted at Waterval in the Standerton district, calling upon them to continue the struggle to the bitter end. It was also decided that Smuts would lead a new invasion of the Cape Colony and Botha of Natal, to relieve the pressure on the two republics.

Shortly afterwards, in Reitz on 11 July, President Steyn narrowly escaped being captured for a second time. From the documents that fell into British hands, Kitchener learned of the irresolution of the Transvaal government - to him proof that his scorched earth policy was bearing fruit. But his proclamation of 7 August 1901 demanded the surrender of all Boers by 15 September. Continued resistance would mean the permanent banishment of all Boer officers and members of the governments and the confiscation of their property. This, however, failed to achieve the desired effect.

In the meantime the resistance of Kritzinger and Scheepers in the Cape Colony was stimulated by the arrival of small commandos under Fouché, Lategan, Wynand Malan, Jan Theron and Manie Maritz. In May 1901 Kitchener sent French to the Cape Colony. With Middelburg as his headquearters, French was to use his 50000 troops to eliminate the roughly 3,000 burghers, who were dispersed over a wide and difficult terrain, and were active from Aliwal North in the east to Port Nolloth in the west, and from Philipstown in the north to very near Cape Town in the south. 
French's task became even more difficult when in September 1901 Smuts crossed the Orange River near Aliwal North with 250 men, taking the struggle in the Cape into a new phase. The Colony was to be part of the theatre of war to the end.

Smuts was harassed continuously on his journey, which took him first towards the Eastern Province, then the southwestern districts and eventually to the northwestern districts of the Cape. Early in January 1902 he met up with Manie Maritz (by now General) in the northwest Cape. With General J. van Deventer, they took the offensive in the vicinity of Okiep, occupying Springbok and Concordia in April 1902.

The British authorities declared martial law in the Cape Colony, removing draught animals from the farms and punishing rebels severely. But this did not deter Cape Afrikaners from offering the invading commandos their hospitality and assisting them in their difficult mission. The war had placed the Cape Afrikaners in a serious dilemma. Though most of them did not hesitate to affirm publicly their loyalty to the Crown, and to make it clear to the invading republican forces that their presence was embarrassing, Cape Afrikaners were in many cases bound to the republicans by blood and cultural ties. The war was therefore for them a great source of affliction.

Though the majority of Cape Afrikaners chose the path of loyal resistance, there were several thousand who joined the invading commandos as rebels. They were swayed not only by sympathy with the Boer cause, but by false claims by the commandos, and even by force. A total of 12828 Cape Afrikaners were ultimately brought to court on charges of high treason, of whom 9747 were found guilty. This presented about ten percent of the whites in the Cape.

In the Free State the guerrilla war was still characterised by Boer attacks on isolated British columns, patrols and convoys. But the British were now also deploying cavalry and 'bagging' smaller commandos in nocturnal attacks. Before dawn on 25 December 1901 De Wet launched a highly successful attack on a British column on the crest of Groenkop, between Bethlehem and Harrismith. Some 500 burghers swarmed up the steep and poorly guarded western slope of the hill and overwhelmed the 470 British soldiers in their sleep. Among the 58 British who were killed was the commander, Major F. Williams. The Boers found the food and ammunition taken as booty a welcome Christmas gift.

It was at this stage that Kitchener introduced his 'new model drives'. More blockhouses had been erected and he was now in a position to co-ordinate his drives more efficiently. These in fact became great sweeps during which his columns, stretched out in lines easily $80 \mathrm{~km}$ long, ousted the Boers from the theatre of the war.

During February and March 1902, Kitchener deployed as many as 30000 troops and several armoured trains in three attempts to trap De Wet against the railway line in the northeastern Free State. Though Kitchener did not succeed in catching as many Boers as he had hoped, the new model drives were a success. The constant pursuit had an adverse effect on Boer morale, and the British destroyed food supplies as they swept across the land. With the winter of 1902 approaching, this became a serious factor in the duration of the Boer struggle. 
In September 1901 Botha organised a sortie with 2000 men to invade Natal again, in order to entice a number of British columns out of the Transvaal. However, the high water level of the Buffalo River, and the fact that the way was barred by 20000 British troops, put paid to Botha's plans. He did, however, successfully apply the Boers' new tactic of horseback charges against the British at Blood River's Poort on 17 September. But his unsuccessful attacks on the British posts at Itala and Fort Prospect nine days later decided the issue.

On 30 October 1901 Botha compensated for his reverses when he once again mustered his commandos with impressive speed and defeated an isolated column under the competent Lieutenant-Colonel G.E. Benson in a horseback charge at Bakenlaagte. Benson, who had been harassing the commandos in the Eastern Transvaal by their own methods, was fatally wounded in the attack. Though there were still to be many more skirmishes in the Eastern Transvaal, they had little effect on the outcome of the war.

In the Western Transvaal the approach of the spring of 1901 heralded a busy time for both sides. One after the other, British commanders were sent out to capture De la Rey. All of them - Methuen, Babington, Dixon, Cunningham, Clements and Kekewich included - had to sound the retreat with some losses. At the start of 1902 Methuen was still hunting De la Rey, whose mobility had been severely limited by Kitchener's blockhouse lines. The British, assisted everywhere by 'joiners' (Boers who had crossed to the British side), were now also setting out on great nocturnal drives to round up the Boers. However, De la Rey successfully employed the horseback charge tactic on the British when they were on the move, as was shown at Yzerspruit on 25 February 1902. Colonel Anderson lost 183 men, killed or wounded; De la Rey released his 500 prisoners the next day.

The Battle of Tweebosch on the Little Harts River on 7 March 1902 once more proved De la Rey's aptitude as a cavalry commander. His veterans stormed the rearguard of Methuen's convoy in mounted formation, firing from the saddle with deadly accuracy. It was De la Rey's most brilliant victory.

The Boer losses of 34 were small in comparison with the 189 British soldiers killed or wounded and the 859 taken prisoner. Methuen, wounded in the leg, fell into Boer hands, but with characteristic magnanimity De la Rey released him so that he could obtain better medical attention with the British than the Boers were able to offer.

Victory in the Battle of Roodewal near the Harts River on 11 April 1902 went to the British. With De la Rey engaged in the peace talks, General J. Kemp attempted to storm the combined forces of Colonels Grenfell, Kekewich and Von Donop, but was beaten off. Some of the Boers were taken prisoner, 43 were killed and 120 were wounded. Roodewal was the last important battle of the war.

Peace came after two years and eight months of war. The first move was a missive from the Dutch Prime Minister, Dr Abraham Kuyper, sent to the British government on 25 January 1902, offering his government's services as mediator. Realising that the Free State leaders would oppose peace movements, Kitchener sent copies of his correspondence on the subject only to the Transvaal government. The outcome was that the two Boer governments met at Klerksdorp on 9 April and with 
Kitchener in Pretoria three days later. It was decided that the burghers still in the field should elect a number of delegates to meet at Vereeniging and decide whether to enter into peace negotiations with the British, with or without recognition of the independence of the republics.

Between 15 and 17 May sixty delegates from the Transvaal and Free State commandos held talks under the chairmanship of General Beyers at Vereeniging. President Steyn, who had contracted a muscular paralysis, attended only one or two of the meetings. Some of the delegates were in favour of surrender, while others insisted on continuing the struggle. The plight of the women and children in the concentration camps; the increasing threat posed by armed blacks to both the burghers on commando and to Boer families roaming the veld; the devastation of the land in the two republics and the resultant shortage of food - all these were powerful arguments for ending the war.

Representatives of the two republican governments submitted the delegates' proposals to Kitchener and Milner in Pretoria on 19 May. The most important was the republics' readiness to sever their foreign ties and accept a British protectorate. Kitchener and Milner firmly refused to conduct negotiations on any basis but the complete surrender of their independence by both republics.

Smuts and Hertzog proceeded to work out terms of peace with Milner. On 21 May their proposals were sent to Britain for government approval. These provided for the burghers on commando to lay down their arms and acknowledge Edward VII as their sovereign; prisoners of war would be repatriated to the Transvaal and Orange River Colony, provided they took the oath of allegiance to the Crown, in which case they would be allowed to retain their personal possessions and their freedom; the Dutch language would be taught at school and permitted in the courts; as soon as circumstances allowed, self-government would be granted to the Transvaal and the Orange River Colony; and the issue of the vote to the blacks would not be decided before the former republics attained self-government; Britain would make a sum of $£ 3$ million available for the reconstruction of the two devastated regions.

Between 29 and 31 May the Boer delegates met again at Vereeniging. At length they voted with heavy hearts 54 for, and six against, the peace terms formulated in Pretoria.

On the evening of 31 May 1902 the Peace Treaty of Vereeniging was signed by the members of the two Boer governments and Kitchener and Milner at Melrose House in Pretoria. The Boers had lost their independence. 


\section{Bibliography}

Amery, L.S. (ed), The Times history of the war in South Africa. 7 Vols., London, 19001906.

Breytenbach, J.H., Die geskiedenis van die Tweede Vryheidsoorlog in Suid-Afrika, 1899-1902. 6 Vols. Pretoria, 1969-1996.

Farwell, B., The Great Anglo-Boer War. London, 1976.

Kruger, R., Good-bye Dolly Gray: the story of the Boer War. London, 1959.

Maurice, F.M. and Grant, M.H., History of the war in South Africa, 1899-1902 (The Official history of the war in South Africa). 4 Vols. and 4 vols. maps, London, 19061910.

Nasson, B., The South African War 1899-1902. London, 1999.

Pakenham, T., The Boer War. London, 1979.

Pretorius, F., The Anglo-Boer War 1899-1902. Cape Town, 1985.

Scholtz, G.D., Die Tweede Vryheidsoorlog 1899-1902. Johannesburg, 1960. 